\title{
POLITICAL SCIENCES
}

\section{THE CURRENT STATE OF RELATIONS BETWEEN THE EU AND US IN THE FIELD OF EUROPEAN SECURITY}

\section{Olga Romanova ${ }^{1}$}

DOI: https://doi.org/10.30525/978-9934-588-39-6-40

In 2018, French President E. Macron and German Chancellor A. Merkel once again stated the necessity of creating a «real European army» independent of the United States that would allow Western Europe to «better protect itself» [1]. It would be wise to mention, that this idea is not new in the history of the formation of the «EU military-political dimension,» but at the present stage, in the context of the emergence of new challenges and threats to European security, it is gaining new importance and becoming more relevant.

Nowadays, the European Union holds 17 military and civilian (mixed) operations and missions in various regions of the world and usually takes part in resolving conflicts of low intensity. European states have not been able to supplement or replace US resources in high-intensity military operations yet.

In particular, in the Concordia operation conducted under the auspices of the EU in Macedonia under the formula «Berlin Plus,» the role of the European Union was negligible. In fact, the EU's first military operation was not an independent event, but merely an integral part of NATO's major Harmony operation. The European Union's forces numbered 300 people. Their task was to ensure the security of EU and OSCE representatives, who monitored the implementation of the Ohrid Framework Agreement. This operation, insignificant from a military point of view, was of great political importance. For the first time, EU observers acted under the protection of the EU military, without the involvement of national governments, NATO allies, or UN peacekeepers. The experience was successful.

In Operation Althea, which has been conducted in Bosnia and Herzegovina since 2004, according to the Berlin Plus formula, the EU contingent has become the official successor to NATO-led SFOR and IFOR contingents. It should be noted that this was the first case of subordination of foreign military forces of the European Union (outside of bilateral national treaties or partnerships within NATO or UN mandates). However, the independence of the European Union military structures is relative. The

${ }^{1}$ Odesa I.I. Mechnikov National University, Ukraine 
European Union Military Headquarters uses the Allied High Command (NATO) in Europe as its operational headquarters and works through the Deputy High Commander, who is, however, necessarily a European officer. The European Union forces have undertaken all NATO tasks, except for the hunt for war criminals.

The Artemis operation, which was conducted in the Democratic Republic of the Congo, was carried out mainly by the French military. The CSDP contingent of about 2,000 people ( $85 \%$ - French, mostly paratroopers) was quickly deployed to Bunia, the centre of the conflict. Belgium, the United Kingdom, Germany, and Greece participated together with France. Neutral Sweden also sent its contingent. The Congo Peacekeeping Mission became the third (and first outside Europe) operation by the European Union Force. The European Council endorsed the launch of the EU military operation and appointed German and French commanders.

The ambiguous US attitude to the role of Western Europe in the European security system affects the whole dynamics of the CSDP. According to Michael Howard, «NATO has developed a military-political infrastructure that has united the armed forces of most European countries and provided the United States with a unique opportunity to influence the policies of its allies...» [2, p. 172]. Nowadays, the United States within NATO is in control of intelligence, with the basic tools of analysis and communication, and has a high capacity for rapid response, delivery of military contingents, weapons and humanitarian assistance to any crisis point in the world. Because of their dominant position in the Alliance, they have been given the opportunity to influence the security policies of Western European countries by virtue of the unanimity principle that determines the decisions of the Atlantic Council, the United States remains the host of the game, defining the operation in which they participate or instructing Europe to carry out an action in which they are not directly involved [3, p. 194]. In this context, French General Francois Valentine noted, «if Europe does not solve this problem for at least 10 years, it would become a US satellite for security» [4, p. 38].

The concentration of Western European military-political cooperation in NATO, in which the US occupies a leadership position, sets the limits for the development of European integration in the fields of foreign policy, security and defence. Consequently, changing the framework conditions transforming transatlantic relations through greater responsibility for European countries - would allow them to consistently and proactively enhance the potential of political and practical interaction in foreign policy and security, including defence.

The United States, for its part, is not satisfied with the cost of maintaining NATO, as they finance a large part of the organization's budget. According to 
Stockholm International Peace Research Institute US military budget in 2018 amounted to 649 billion dollars, while the five largest European defence budgets (France, UK, Germany, and Spain) - 209 billion dollars [5]. Therefore, objective prerequisites for the redistribution of responsibilities between European members of the Alliance and the United States in the field of security and defence have emerged.

The NATO Strategic Concept emphasizes that developing a European identity in security and defence, which is reflected in the strengthening of European support in the Alliance, will not only serve the interests of European countries but also enhance the unity and effectiveness of the Alliance as a whole. This provision clearly characterizes the essence of the US-West European compromise and the balance of interests reached by NATO, which is characteristic of the entire subsequent period of its development. The United States has been able to influence European activity and reduce its competitive potential while retaining its leadership position and has found a strong motive for pressuring the Allies to make greater contributions to NATO. Western European countries, in turn, have been given the opportunity to overcome the American barrier to developing their own security and defence cooperation, while avoiding the erosion of the US role in Europe. Thus, NATO and the US recognized the need to create a European component to complement and strengthen transatlantic security cooperation. It should be noted that the issue of enhancing European identity in security and defence was not entirely new to the North Atlantic Alliance. But with the formation of a new European security system, this problem has taken on other features.

Two options for EU involvement in peacekeeping are being considered in Brussels: using Allies resources (based on Berlin Plus arrangements) or relying on the military capabilities of an EU member state to host the operation. Most attention is given to crisis areas in the immediate vicinity of the EU borders (the Balkans, North and Central Africa, the Middle East).

In 2016 the European Union Global Strategy was introduced, which have given the CSDP a new impetus. EU-NATO cooperation constitutes an integral pillar of the EU's work aimed at strengthening CSDP, as part of the implementation of the EU Global Strategy. It also contributes to TransAtlantic burden sharing. On July 2016, the President of the European Council and the President of the European Commission, together with the Secretary General of the North Atlantic Treaty Organization signed a Joint Declaration in Warsaw with a view to giving new impetus and new substance to the EUNATO strategic partnership. Declaration outlined seven concrete areas where cooperation between the two organisations should be enhanced: 1 . countering hybrid threats; 2. operational cooperation including at sea and on migration; 3 . cyber security and defence; 4 . defence capabilities; 5 . defence industry and 
research; 6. exercises; 7. supporting Eastern and Southern partners' capacitybuilding efforts [6]. On the basis of the mandate by the Joint Declaration, common sets of proposals were endorsed by the EU and NATO Councils in December 2016 and 2017. Four progress reports have been submitted highlighting main achievements and added value of EU-NATO cooperation in different areas. On 10 July, 2018, the President of the European Council and the President of the European Commission, together with the Secretary General of the North Atlantic Treaty Organization signed a second Joint Declaration in Brussels calling for swift and demonstrable progress in implementation.

The strategic partnership between the EU and NATO is currently reflected at tactical and operational level in the existing cooperation and coordination between EUNAVFOR MED Operation Sophia (ENFM) and Operation Sea Guardian in the Central Mediterranean. The two military operations actively exchange information.

Cooperation between the EU and NATO is now the established norm and daily practice and continues to take place on the basis of key guiding principles: openness, transparency, inclusiveness and reciprocity, in full respect of the decision-making autonomy and procedures of both organisations without prejudice to the specific character of the security and defence policy of any Member State.

\section{References:}

1. Merkel joins Macron in calling for a 'real, true European army'. The Guardian. (November 13, 2018). Retrieved from: https:/www.theguardian.com/world/ 2018/nov/13/merkel-joins-macron-in-calling-for-a-real-true-european-army (accessed 27 February 2020).

2. Howard M. (1999). An Unhappy Successful Marriage. Security Means Knowing What to Expect. Foreign Affairs, Vol. 78, no. 3, pp. 164-175.

3. Jessel J. (1997). Le XXI siècle: avec ou sans la France? Paris: L'Harmattan, 1997.

4. Viriot J.-M. (2011). L'autonomie, clé de voûte d'une véritable défense européenne. Défense nationale, no. 2, pp. 35-44.

5. Tian N., Fleurant A., Kuimova A., Wezeman P. D., Wezeman S. T. (2019). Trends in world military expenditure, 2018. SIPRI Fact Sheet (April 29, 2019). Retrieved from: https://www.sipri.org/sites/default/files/2019-04/fs_1904_milex_ 2018.pdf (accessed 26 February 2020).

6. EEAS homepage (2019). EU-NATO cooperation. Factsheets, Bruxelles (June 06, 2019). Retrieved from: https://eeas.europa.eu/headquarters/headquartershomepage/28286/eu-nato cooperation-factsheet_nl (accessed 26 February 2020). 